\title{
SILK FIBROIN NANOPARTICLES REVEAL EFFICIENT DELIVERY OF 5-FU IN A HT-29 COLORECTAL ADENOCARCINOMA MODEL IN VITRO
}

\author{
IONUȚ CRISTIAN RADU ${ }^{1}$, ARIANA HUDIȚA ${ }^{2}{ }^{2}$ CĂTĂLIN ZAHARIA ${ }^{1}$, CAROLINA NEGREI $^{3}$, \\ GEORGE TRAIAN ALEXANDRU BURCEA DRAGOMIROIU ${ }^{4}$, DANIELA ELENA POPA ${ }^{4}$, \\ MARIETA COSTACHE $^{2}$, HORIA IOVU ${ }^{1}$, MARA GEORGESCU ${ }^{7 *}$, OCTAV GINGHINA ${ }^{5,6}$, \\ BIANCA GĂLĂȚEANU ${ }^{2}$
}

${ }^{1}$ Advanced Polymer Materials Group, Politehnica University of Bucharest, Bucharest, Romania

${ }^{2}$ Department of Biochemistry and Molecular Biology, University of Bucharest, Romania

3 "Carol Davila" University of Medicine and Pharmacy, Faculty of Pharmacy, Department of Toxicology, Bucharest, Romania

4 "Carol Davila” University of Medicine and Pharmacy, Faculty of Pharmacy, Department of Drug Control, Bucharest, Romania

${ }^{5}$ Department of Surgery, "Sf. Ioan" Clinical Emergency Hospital, Bucharest, Romania

6 "Carol Davila" University of Medicine and Pharmacy, Faculty of Dental Medicine, Department II, Bucharest, Romania

${ }^{7}$ University of Agronomic Sciences and Veterinary Medicine of Bucharest, Faculty of Veterinary Medicine, 59 Mărăşti

Boulevard, Bucharest, 011464, Romania

*corresponding author: dr_georgescu_mara@yahoo.com

Manuscript received: July 2020

\begin{abstract}
The aim of the paper was to investigate the efficiency of 5-FU delivery from smart silk fibroin nanoparticles in a HT-29 colorectal adenocarcinoma model in vitro. Therefore, nanoparticles with various amounts of silk fibroin were obtained by nanoprecipitation method and characterized to evaluate the 5-FU encapsulation efficiency and release profile. All nanoparticles showed a good entrapment of the drug and were capable to release 5-FU in a polymer concentration dependent manner. The in vitro biological evaluation revealed an excellent biocompatibility of the pristine silk fibroin nanocarriers, while 5-FU loaded nanoparticles proved to be highly cytotoxic and dramatically decreased the HT-29 cellular viability and proliferation potential. More, the 5-FU silk fibroin nanoparticles induced alterations in the HT-29 cellular morphology and inhibited the formation of compact cellular clusters.
\end{abstract}

\section{Rezumat}

Scopul lucrării a constat în investigarea eficienței de administrare a 5-FU eliberat din nanoparticule de fibroină de mătase, într-un model de cancer colorectal in vitro. Astfel, au fost obținute nanoparticule cu concentrații variate de polimer prin metoda nanoprecipitării, caracterizate din punct de vedere al eficienței de încapsulare a 5-FU şi al profilului de eliberare a substanței active încapsulate. Toate nanoparticulele au prezentat o bună eficiență de încapsulare și au eliberat substanța activă din structura lor într-o manieră dependentă de concentrația de polimer utilizată în procesul de obținere. Evaluarea nanoparticulelelor in vitro a evidențiat o excelentă biocompatibilitate a nanoparticulelor de fibroină de mătase neîncărcate, în timp ce nanoparticulele încărcate cu 5-FU au prezentat citotoxicitate crescută, scăzând semnificativ viabilitatea celulară şi potențialul proliferativ al celulelor HT-29. Mai mult, nanoparticulele încărcate cu 5-FU au indus modificări ale morfologiei celulare a celulelor HT-29 și au inhibat formarea grupurilor compacte de celule.

Keywords: 5-FU, silk fibroin, nanoparticles, HT-29 adenocarcinoma cells, drug delivery systems

\section{Introduction}

Currently, colorectal cancer (CRC) is a major public health problem worldwide being among the most lethal malignancies both in man and woman. Due to the implementation of CRC screening programs that favour an early diagnosis, the CRC mortality trend is decreasing in Europe, but unfortunately in Romania CRC remains a critical health emerging issue based on the latest high mortality rates reported [1]. Despite the advances in identifying effective chemopreventive agents [2-4], primary and adjuvant treatments [5, 6] and therapy personalization approaches [7] the poor survival rates observed in CRC patients highlight the need to improve the current therapeutic strategies. In this context, cancer nanomedicine field has gained a lot of interest during recent decades as it holds great potential to improve the efficacy of therapy and to overcome multidrug resistance.

Cancer nanomedicine combines the knowledge and tools of nanotechnology to develop advanced nanosized systems that can efficiently deliver anticancer agents to targeted cancer cells. Not only that nanomedicine implies the miniaturization of large materials for medical purposes, but it also aims to develop smart nanomaterials with controlled chemical and physical capabilities, tailored to the desired application [8-12]. 
For designing and obtaining novel nanocarriers, biocompatibility, biodegradability and surface chemistry are crucial parameters for their prospective use as drug delivery systems, as well for their ability to target the desired tissue. Therefore, natural or synthetic polymers are intensively used in nanotechnology due to their general high biocompatibility [13-17]. Moreover, various natural or synthetic polymers are biodegradable and undergo cleavage into low molecular weight compounds in physiological environments [18-19]. The biodegradable polymers can be used for developing nanospheres, core-shell nanoparticles, polymer-based micelles or polyplexes [20-24]. Among the numerous polymers choices for nanoparticle development, silk fibroin (SF) is one of the most popular biopolymers due to its excellent biocompatibility, high abundance and low costs. The unique chemical structure of SF allows high ability to take part in various interactions, being able to attach physically or covalently various modifiers, ligands or drugs [2527]. SF based nanoparticles have been developed for administration of both hydrophilic and hydrophobic drugs [28, 29], or other bioactive molecules [30, 31]. The encapsulation of the drugs in nanosized systems is required due to the short-life, poor bioavailability and rapid metabolic degradation of the compounds upon administration [32, 33]. Moreover, the tissue distribution of the drug is generally limited as many of these compounds fail to penetrate the biological barriers encountered. The golden standard treatment for CRC, 5-fluorouracil (5-FU), presents a low response rate and poor bioavailability, as well as high cytotoxicity [34]. Therefore, potential drug-delivery systems that can improve 5-FU treatment efficacy and diminish the side effects are needed. The water-soluble 5-FU qualifies as a candidate drug for encapsulation in SF based drug-delivery systems.

In this context, the aim of the present study was to investigate the efficiency of 5-FU delivery from smart silk fibroin nanoparticles in a HT-29 colorectal adenocarcinoma model in vitro. The anticancer efficacy of the novel SF nanoparticles loaded with 5-FU was evaluated in a HT-29 colorectal adenocarcinoma model in vitro, evaluating the cell viability, proliferation potential and probable alterations of the cell structure as response to treatment.

\section{Materials and Methods}

\section{Obtaining of silk fibroin nanoparticles}

Purification of silkworm cocoons

Prior silk fibroin (SF) solution preparation, the SF fibres were subjected to a purification step for separating the fibres from cocoon products. The Bombyx mori silkworm cocoons were processed as previously described [35] in order to remove sericin, various waxes and other impurities. The degumming procedure was repeated several times until clean SF fibres were obtained. The recovered SF fibres were thoroughly washed with distilled water for salts and surfactants removal and finally dried at $40^{\circ} \mathrm{C}$.

Preparation of silk fibroin solution

The obtained SF fibres were dissolved step by step in a $9.5 \mathrm{M}$ lithium bromide solution at $60^{\circ} \mathrm{C}$ for several hours and left for an additional $24 \mathrm{~h}$ on a magnetic stirrer. Then, the SF solution was dialyzed for a week in distilled water using dialysis tubing cellulose membrane to fully remove lithium bromide ions. Finally, various SF aqueous solutions with different concentrations (1, 2, 3 and 4\%) were obtained and kept until use at $4{ }^{\circ} \mathrm{C}$ to avoid precipitation.

Obtaining of silk fibroin nanoparticles

According to Zhang Yu-Qing et al. experimental observations [36] the design and obtaining protocol was optimized to generate SF nanoparticles with predictable and controllable size. Briefly, the SF solution was added dropwise in a water-miscible organic solvent (acetone), under high stirring with a controlled flow at room temperature. The volume ratio between SF solution and non-solvent solution (acetone) was fixed at $1 / 9(\mathrm{v} / \mathrm{v})$. The resultant solution was stirred at high speed at $50^{\circ} \mathrm{C}$ and atmospheric pressure until the solvent and non-solvent evaporated, moment in which the nanoparticles were collected. In order to control the nanoparticles size, the SF concentration varied from $1 \%$ to $4 \%$ (w/v) (SF $1 \%$ - SF $4 \%$ ), while the polymer/non-solvent volume ratio, controlled flow and stirring were kept constant.

Nanoparticles characterization

The obtained silk fibroin nanoparticles (SF NPs) were characterized in terms of drug loading efficacy and release potential.

\section{5-FU drug loading investigation}

Due to the excellent solubility of 5-fluorouracil (5-FU) within the SF solution, the drug was loaded into the nanoparticles by direct dissolution. Therefore, a constant 5 -FU concentration of $0.05 \%(0.5 \mathrm{mg} / \mathrm{mL})$ in polymer phase was obtained for all polymer concentrations $(1 \%-4 \%)$. The encapsulation efficiency (EE) was determined based on the ratio between the weight of 5-FU loaded into the nanoparticles and the total weight of 5-FU initially loaded within the fibroin solution, according to the following equation:

$$
E E(\%)=\frac{\text { weight of } 5-F U \text { loaded in the nanoparticles }}{\text { total weight of the } 5-F U \text { added }} \times 100
$$

5-fluorouracil drug release behaviour investigation In order to investigate the nanoencapsulated 5-FU release trend, the drug loaded nanoparticles were added into a tubular cellulose membrane, immersed in a controlled volume of phosphate buffer saline (PBS, pH 7.45) and incubated in a precision water bath (orbital mixer Benchmark Scientific) at $300 \mathrm{rpm}$ and $37.0 \pm 0.5^{\circ} \mathrm{C}$. At different time points, $5 \mathrm{~mL}$ supernatant was collected and evaluated by UV-VIS spectroscopy, while the collected volume was replaced with $5 \mathrm{~mL}$ of fresh PBS in order to maintain constant 
the initial volume of the sample. The collection time points were every 15 minutes for the first hour, every 30 minutes until 5 hours and every hour until the end of the experiment.

\section{Cell cultures}

HT-29 human adenocarcinoma cell line $\left(\right.$ ATCC $^{\circledR}$ HTB- $38^{\mathrm{TM}}$ ) was purchased from the American Type Culture Collection (ATCC) and cultured in Dulbecco's Modified Eagle Medium (DMEM) supplemented with $10 \%$ foetal bovine serum (FBS) and $1 \%$ antibioticantimycotic solution (ABAM, containing $100 \mathrm{U} / \mathrm{mL}$ penicillin, $100 \mu \mathrm{g} / \mathrm{mL}$ streptomycin and $0.25 \mu \mathrm{g}$ amphotericin B). The cell lines were subcultured weekly and maintained at $37^{\circ} \mathrm{C}$ in a humidified air atmosphere of $5 \% \mathrm{CO}_{2}$ all throughout the experiment. The media renewal was carried out every other day. Determination of DL50 - working dose

The cytotoxic activity of SF NPs + 5-FU was evaluated via 2-(4,5-dimethylthiazol-2-yl)-3,5-diphenyl-2Htetrazol-3-ium bromide (MTT) colorimetric assay. Briefly, HT-29 cells were seeded at an initial density of $2.5 \times 10^{4}$ cells $/ \mathrm{cm}^{2}$ in 96 -well culture plates and treated with the following concentrations of SF NPs + 5-FU: $30 \mathrm{mg} / \mathrm{mL}, 25 \mathrm{mg} / \mathrm{mL}, 20 \mathrm{mg} / \mathrm{mL}, 15 \mathrm{mg} / \mathrm{mL}$, $10 \mathrm{mg} / \mathrm{mL}$ and $1 \mathrm{mg} / \mathrm{mL}$. After $24 \mathrm{~h}$ of treatment, the culture media was discarded from each well and replaced with a freshly prepared solution of MTT $(1 \mathrm{mg} / \mathrm{mL})$. The samples were further incubated for $4 \mathrm{~h}$ in standard cell culture conditions to allow the metabolically active cells to form formazan crystals, which were further dissolved in DMSO. The absorbance of the resulting solutions was measured at $550 \mathrm{~nm}$ using a Flex Station III multimodal reader (Molecular Devices). The in vitro cytotoxicity screening allowed the determination of the lethal dose $50\left(\mathrm{LD}_{50}\right)$ for $\mathrm{SF}$ NPs + 5-FU, concentration that will be further used as working dose for all presented in vitro experiments. In vitro cytotoxicity evaluation of $\mathrm{SF} N \mathrm{NP}+5-\mathrm{FU}$ In order to determine the cytotoxic potential of the SF NPs on the colorectal cancer cells, the following investigations were performed during $72 \mathrm{~h}$ of culture: (i) cell viability and proliferation potential investigation by MTT assay; (ii) cell viability and proliferation potential investigation by Live/Dead fluorescence microscopy assay; (iii) LDH activity evaluation in culture media and (iv) HT-29 cells morphology.

\section{Cell viability assay}

The MTT assay was used to measure HT-29 colon cancer cells viability after incubation with SF NPs and SF NPs + 5-FU. Briefly, HT-29 cells were seeded at an initial density of $2.5 \times 10^{4}$ cells $/ \mathrm{cm}^{2}$ in 96-well culture plates and treated with $20 \mathrm{mg} / \mathrm{mL}$ SF NPs and SF NPs + 5-FU for 24, 48 and $72 \mathrm{~h}$. At each time point, the culture media was discarded, and the samples were processed as described above.

Live/Dead assay

In order to highlight the ratio between live and dead cells in the colon cancer cells culture after exposure to simple or SF NPs + 5-FU, the Live/Dead assay (Invitrogen) was employed. In brief, HT-29 cells were seeded in 6- well culture plates at an initial density of $2 \times 10^{4}$ cells $/ \mathrm{cm}^{2}$ and treated with SF NPs and SF $\mathrm{NPs}+5$-FU $(20 \mathrm{mg} / \mathrm{mL})$. After $24 \mathrm{~h}, 48 \mathrm{~h}$ and $72 \mathrm{~h}$, the cell culture media was discarded and the samples were incubated at room temperature in the dark for $20 \mathrm{~min}$ with the staining solution, prepared fresh according to the manufacturers' instruction. The staining solution consisted of a mixture of fluorescent dyes (calcein AM - green and ethidium bromide - red) that allowed discrimination of dead cells from living cells. The samples were imaged using the Olympus IX73 inverted fluorescence microscope (Olympus) and images were captured using CellSense Imaging Software.

5-FU silk fibroin nanocarriers cytotoxic potential on HT-29 cancer cells

The cytotoxic potential of the SF NPs +5 -FU was investigated by the spectrophotometric evaluation of the lactate dehydrogenase $(\mathrm{LDH})$ activity in the culture media. Briefly, after 24, 48 and 72 h of HT-29 cells exposure to simple and SF NPs + 5-FU (20 mg/ $\mathrm{mL}$ ), the culture media was harvested and mixed with the components of the TOX-7 kit (LDH based in vitro toxicology assay kit, Sigma Aldrich, USA) according to the manufacturers' instruction. After $30 \mathrm{~min}$ incubation at room temperature in the dark, the absorbance of the samples was quantified at 490 $\mathrm{nm}$ using a Flex Station III multi-modal reader (Molecular Devices).

Cytoskeleton investigation and DAPI staining

In order to evaluate the potential alterations induced in the HT-29 colon cancer cells cytoskeleton structure by SF NPs + 5-FU treatment, the actin filaments were stained with FITC (fluorescein isothiocyanate) phalloidin. In this view, HT-29 cells were seeded in 6 -well culture plates at an initial density of $2 \times 10^{4}$ cells $/ \mathrm{cm}^{2}$ and treated with SF NPs and SF NPs + 5-FU $(20 \mathrm{mg} / \mathrm{mL})$ for 24,48 and $72 \mathrm{~h}$. At each time point, the HT-29 monolayers were fixed with a $4 \%$ paraformaldehyde solution for 20 minutes, permeabilized with a $2 \% \mathrm{BSA} / 0.1 \%$ Triton X100 solution for $1 \mathrm{~h}$ and consequently stained with FITC-conjugated phalloidin for $1 \mathrm{~h}$ at $37^{\circ} \mathrm{C}$ in a humid environment. In the end, the HT-29 monolayers were stained with DAPI (4',6-diamidino-2-phenylindole) in order to highlight cell nuclei and reveal chromatin fragmentation. The samples were analysed using the Olympus IX73 inverted fluorescence microscope (Olympus) and images were captured using CellSense Imaging Software.

Statistical analysis

The data obtained were statistically analysed using GraphPad Prism 6 software, one - way ANOVA and the Bonferroni test. All the experiments were performed with 3 biological replicates and each data set is presented as the average of 3 replicates (mean \pm standard deviation). A value of $\mathrm{p}<0.05$ was considered to indicate a statistically significant difference. All 
experimental controls were represented by HT-29 cells cultures where fresh culture media was added instead of nanoparticles treatment and were identical processed as described for each assay separately.

\section{Results and Discussion}

Silk fibroin nanoparticles obtaining mechanism In order to obtain silk fibroin nanocarriers an optimized protocol of nanoprecipitation was employed due to the polymer's chemistry. Therefore, stable SF NPs with varying concentrations of SF $(1-4 \%)$ were obtained and subsequently loaded with 5-FU.

Generally, the nanoprecipitation process is divided in three main stages: nucleation (initiation), growth and aggregation [37, 38]. SF is considered a semicrystalline biopolymer, which shows two types of crystalline structures, $\alpha$-helix and $\beta$-sheets and an amorphous phase. More, SF is a water-insoluble fibrous protein due to the crystalline domain, which assumes a high ordered arrangement of hydrophobic amino acids such as glycine and alanine. As a result of the hydrophobic nonpolar amino acids and the highly degree of intermolecular physical interactions, the water molecules are not capable to penetrate and dissolve the molecules. Therefore, the dissolution can be achieved only by high concentration of salts that are capable to break the existent physical interactions. After dissolution, the salt ions are removed by dialysis against water, leading to water stable fibroin molecules due to the contribution of polar amino acids (serine, lysine, tyrosine). Therefore, the composition of fibroin consisting in both polar and nonpolar amino acids can induce an amphiphilic character or surfactant character.

Regarding the choice of the non-solvent, acetone has water miscibility and induces rearrangement of fibroin chains by achieving a higher crystallinity. In this regard, acetone cannot induce a classical insolubility for fibroin chains with fast phase collapsing. In the initial stage of the nanoprecipitation mechanism, the amphiphilic character allows fibroin chains to induce a local super-saturation, which generates nucleation of multiple nuclei without aggregation. The initial nuclei start to grow with similar rate by addition of new chains. The new chains addition can be sustained by the solvent diffusion through acetone phase. During diffusion, the water molecules can transport solvated fibroin molecules which reach initial nuclei and adhere on the surface. No aggregation within the initial stage allows maintaining of nanoparticles number until the final stage. After growth step, the nanoparticles reach bigger sizes which force them to interact and collapse probably because of increasing size in the same volume (Figure 1). This mechanism can explain why a higher amount of fibroin produces larger number of nanoparticles. The nuclei are kept until the final stage. Here they start to collapse due to lack of space and the aggregation step begins.
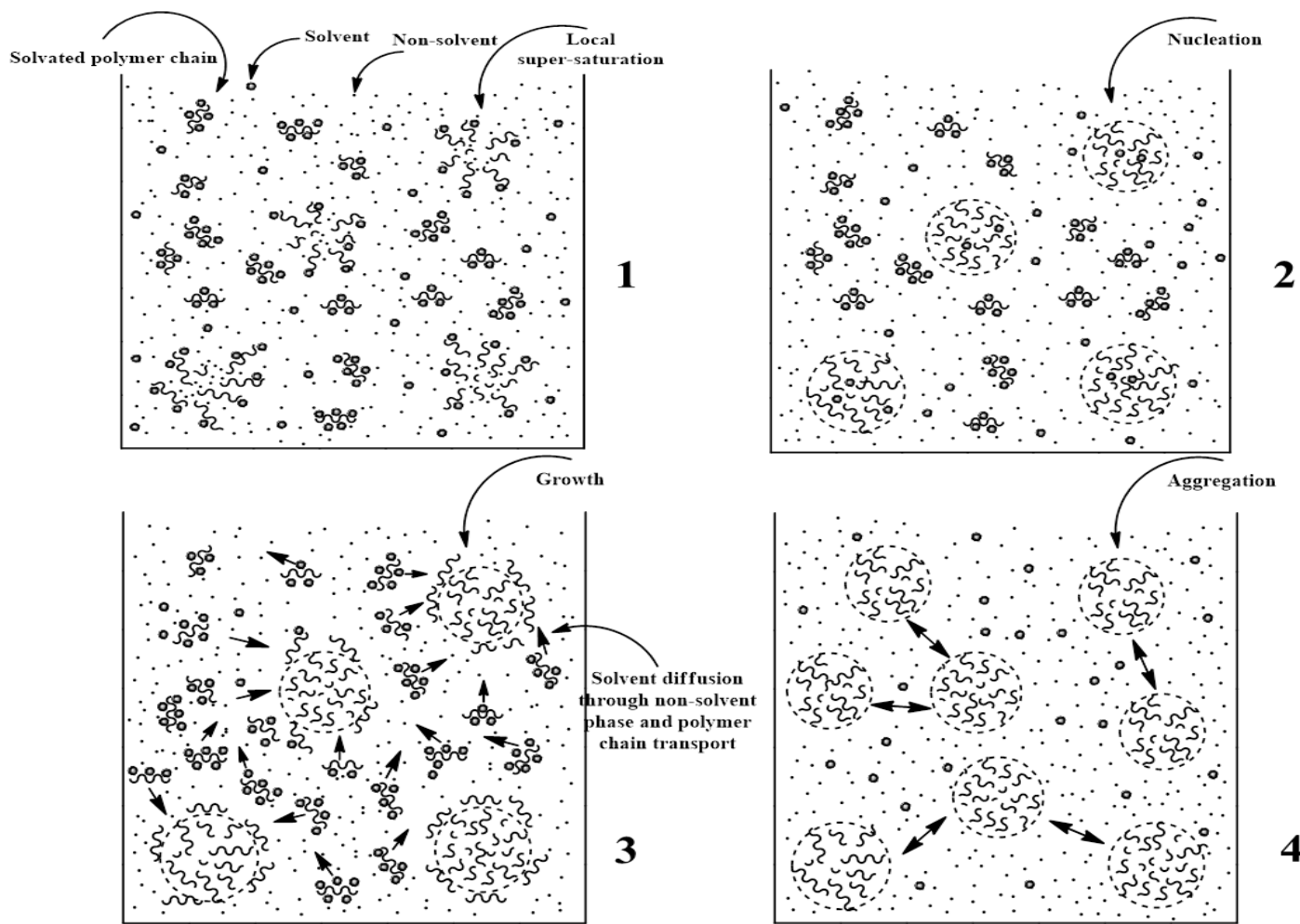

Figure 1.

Fibroin nanoparticles pathway mechanism by nanoprecipitation in acetone and nanoparticles structure: (1) pre-nucleation/process parameters setting; (2) nucleation; (3) growth; (4) aggregation 
The generated nanoparticles are water stable without exhibiting further dissolution. Most probably, the highly ordered hydrophobic domains interpose the acetone phase surface while less ordered and more hydrophilic domains achieve the core nanoparticles. In this regard, the highly ordered hydrophobic domains contain small non-polar aminoacids including glycine, alanine or valine while more hydrophilic domains contain larger polar aminoacids such as tyrosine or phenylalanine (Figure 2). The stabilization can be explained by new physically inter- and intramolecular interactions achieved within fibroin structure. These physical interactions are favoured by the converting of less ordered domain (random coil) towards more stable ordered domains. The adding of fibroin into a non-solvent such acetone leads to a coacervation or precipitation process by changes in crystalline structure conformation from amorphous structure and $\alpha$-helix to a thermodynamic stabile $\beta$-sheet structure. This approach involves obtaining of physical crosslinking bonds [39]. Thus, the acetone as precipitation nonsolvent allows obtaining of silk nanoparticles dimensionally stable by physical crosslinking with size control ability.

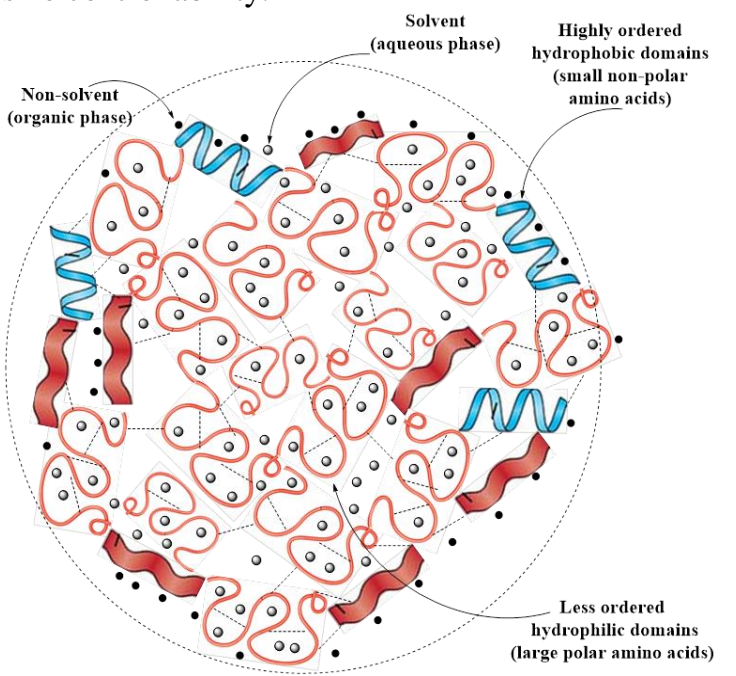

Figure 2.

Fibroin nanoparticles during nucleation step

\section{Drug release curves for 5-FU from silk fibroin nanoparticles}

5-FU was entrapped within all silk fibroin formulations (1 - 4\%) and all the SF NPs were characterized in terms of encapsulation efficiency and drug release capacity. The theoretical encapsulation efficiency was found to be $90-95 \%$. The high encapsulation efficiency for 5-FU was favoured by its good water solubility that lead to a high distribution of drug molecules within the SF aqueous solution.

The drug release efficiency was estimated at $93 \%$ for SF $1 \%, 92 \%$ for SF $2 \%, 95 \%$ for SF $3 \%$ and $97 \%$ for SF $4 \%$. The drug release curves for 5-FU loaded SF NPs (Figure 3) highlighted that the variation of SF amount impacts on the release speed of 5-FU from the nanosystems. Therefore, 3\% SF NPs and 4\% SF NPs presented a faster release profile from the carriers (70 - 80\%), in comparison with the $1 \%$ SF NPs and $2 \%$ SF NPs. Most likely, at high amounts of SF the physically crosslinking process could lead to a higher physical network density that favoured drug molecules orientation toward surface.

More, the release of 5-FU is also positively influenced by the biodegradation process that allows the leakage of the drug molecules from the polymeric chains [40]. The physical bonds created between the drug and the polymer, the rate of the drug molecules diffusion through polymeric matrix, water solubility degree of the drug or porosity are also key elements involved in the drug release process [39]. In our case, we consider that the 5-FU fast release cannot be attributed to the biodegradation of SF, but to the diffusion and osmosis processes that determined the swelling of the SF NPs and release of the 5-FU molecules. The heavy chain reveals alternating crystalline domains, which are hydrophobic and amorphous domains which are hydrophilic, while the light chains are more elastic and hydrophilic. These important factors allow water molecules to solvate macromolecular chains and take out the drug molecules from the carrier matrix [40].

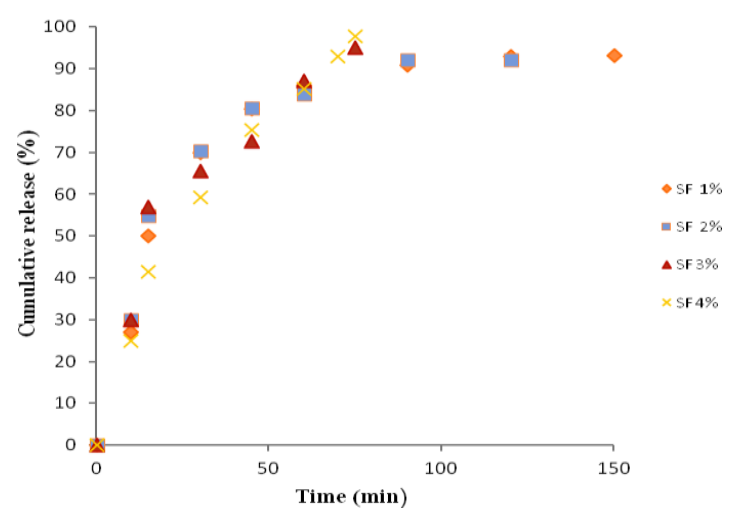

Figure 3.

5-FU release curve for nanoparticles obtained from SF with 1, 2, 3 and $4 \%$ concentration

Lethal Dose (LD50) screening for silk fibroin nanocarriers

In order to determine the working dose for the developed SF nanocarriers, HT-29 cells were treated for $24 \mathrm{~h}$ with the following dilutions of $4 \%$ SF NPs +5 -FU suspension in culture medium: $30 \mathrm{mg} / \mathrm{mL}, 25 \mathrm{mg} / \mathrm{mL}$, $20 \mathrm{mg} / \mathrm{mL}, 15 \mathrm{mg} / \mathrm{mL}, 10 \mathrm{mg} / \mathrm{mL}$ and $1 \mathrm{mg} / \mathrm{mL}$. Then, the cells viability (Figure 4) was evaluated by MTT assay and compared with an untreated reference. Our data show that the dilution of $20 \mathrm{mg} \mathrm{NPs} / \mathrm{mL}$ will reduce to half the cell viability in $24 \mathrm{~h}$ of culture and therefore, it was used as treatment for all further studies. 


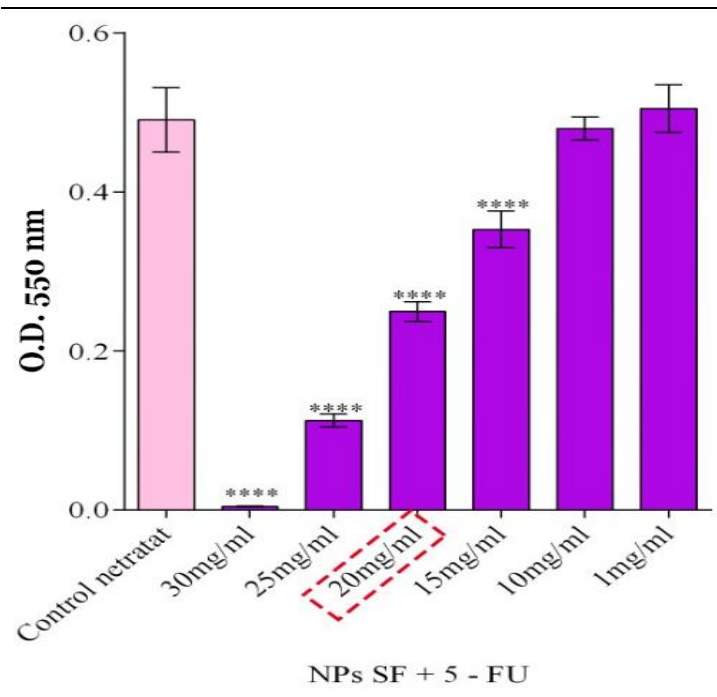

Figure 4.

Graphical representation of cells viability after $24 \mathrm{~h}$ of treatment with $30 \mathrm{mg} / \mathrm{mL}, 25 \mathrm{mg} / \mathrm{mL}, 20 \mathrm{mg} / \mathrm{mL}$, $15 \mathrm{mg} / \mathrm{mL}, 10 \mathrm{mg} / \mathrm{mL}$ and $1 \mathrm{mg} / \mathrm{mL}$ SF NPs $+5 F U$ $v$. an untreated sample, as revealed by the MTT assay $(* * * * \mathrm{p}<0.0001)$

HT-29 cell viability and proliferation potential screening

HT-29 cells viability and proliferation potential was investigated during $72 \mathrm{~h}$ of culture both by MTT quantitative spectrophotometric assay and Live/Dead qualitative fluorescence microscopy assay.

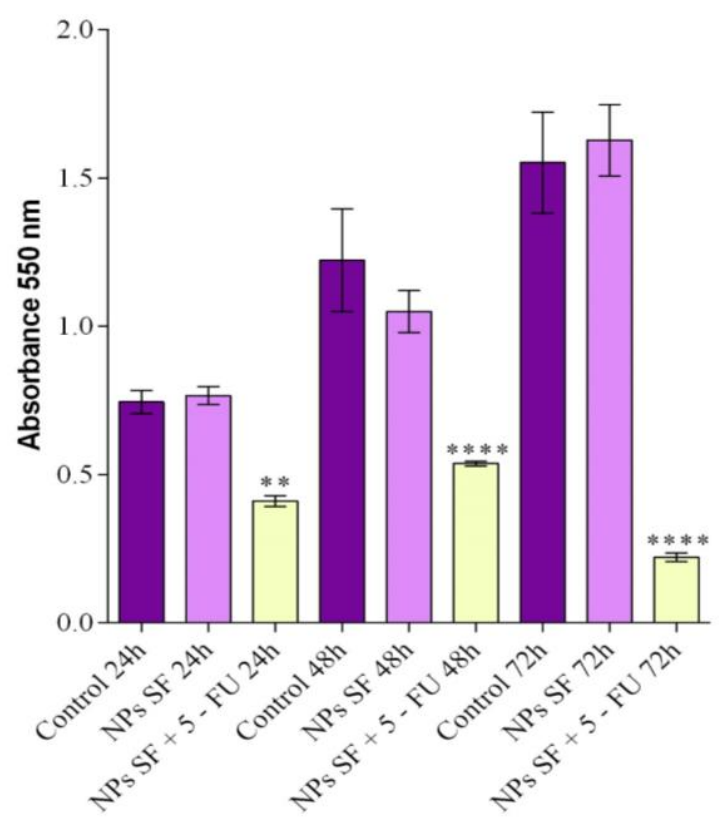

Figure 5.

Graphical representation of cells viability after $24 \mathrm{~h}$, $48 \mathrm{~h}$ and $72 \mathrm{~h}$ of treatment with $20 \mathrm{mg} / \mathrm{mL}$ SF NPs \pm $5 \mathrm{FU}$ vs. an untreated sample, as revealed by the MTT assay

$$
(* * \mathrm{p}<0.01 ; * * * * \mathrm{p}<0.0001)
$$

\section{MTT assay}

To evaluate the viability of HT-29 human colon cancer cells after 24, 48 and 72 hours of exposure to unloaded SF NPs and 5-FU loaded SF NPs, the quantitative MTT assay was performed. Data were statistically analysed and graphically represented in Figure 5 using GraphPad Prism 6 software. Our data show that after 24 hours of treatment, the 5-FU loaded SF NPs significantly decreased HT-29 cells viability as compared with the untreated sample $(* * \mathrm{p}<0.01)$, while the unloaded SF NPs didn't induce any viability alteration. The same profile was observed both at $48 \mathrm{~h}$ and $72 \mathrm{~h}$ of exposure to the treatment, with a higher significance in the cell viability decrease under the treatment with 5-FU loaded SF NPs as compared with the control $(* * * * \mathrm{p}<0.0001)$. More, the untreated cells viability was found significantly increased during the experimental time ( $48 \mathrm{~h} v s .24 \mathrm{~h}$ and $72 \mathrm{~h} v s .48 \mathrm{~h}$ ), as well as the viability of the cells treated with the unloaded SF NPs. In contrast, the treatment with 5-FU loaded SF NPs didn't produce statistical significant alteration during $72 \mathrm{~h}$ and the cells viability was maintained constantly low in this case.

\section{Live/Dead assay}

The above results were further confirmed by the investigation of the monolayers through fluorescence microscopy after Live/Dead staining. For this, the cells treated with unloaded and 5-FU loaded SF NPs as well as an untreated control monolayer were labelled with calcein and ethidium bromide to reveal the ratio between living and dead cells at $24 \mathrm{~h}, 48 \mathrm{~h}$ and $72 \mathrm{~h}$. The images captured were presented in Figure 6 and reveal that both the HT-29 cells treated with unloaded SF NPs as well as the untreated cells did proliferate during the experimental period of $72 \mathrm{~h}$ as the small clusters of living cells observed after $24 \mathrm{~h}$ expanded during time. Few red spots are visible in these images indicating that the ratio between the living and dead cells was in favour of the living ones. In contrast, when treated with 5-FU loaded SF NPs, the monolayers of HT-29 adenocarcinoma cells display a totally different aspect as soon as $24 \mathrm{~h}$ of exposure. The clusters of living cells observed in the untreated sample and even in the samples treated with unloaded SF NPs were not present after the treatment with 5-FU loaded SF NPs. More, after 48 h, many red spots were observed in the samples treated with 5-FU SF NPs, indicating that the cells died under the treatment.

Treatment's cytotoxic potential on HT-29 adenocarcinoma cells

The cytotoxic potential of the SF NPs as well as the 5-FU loaded SF NPs on HT-29 adenocarcinoma cells was investigated by LDH spectrophotometric assay. The data obtained were analysed and graphically represented in Figure 7 using the GraphPad Prism 6 software. 



Figure 6.

Live/Dead fluorescence microscopy images of untreated HT-29 adenocarcinoma cells and HT-29 adenocarcinoma cells treated with unloaded and 5-FU loaded SF NPs for $24 \mathrm{~h}, 48 \mathrm{~h}$ and $72 \mathrm{~h}$

(green fluorescence - living cells stained with calceinAM; red fluorescence - dead cells stained with ethidium bromide)

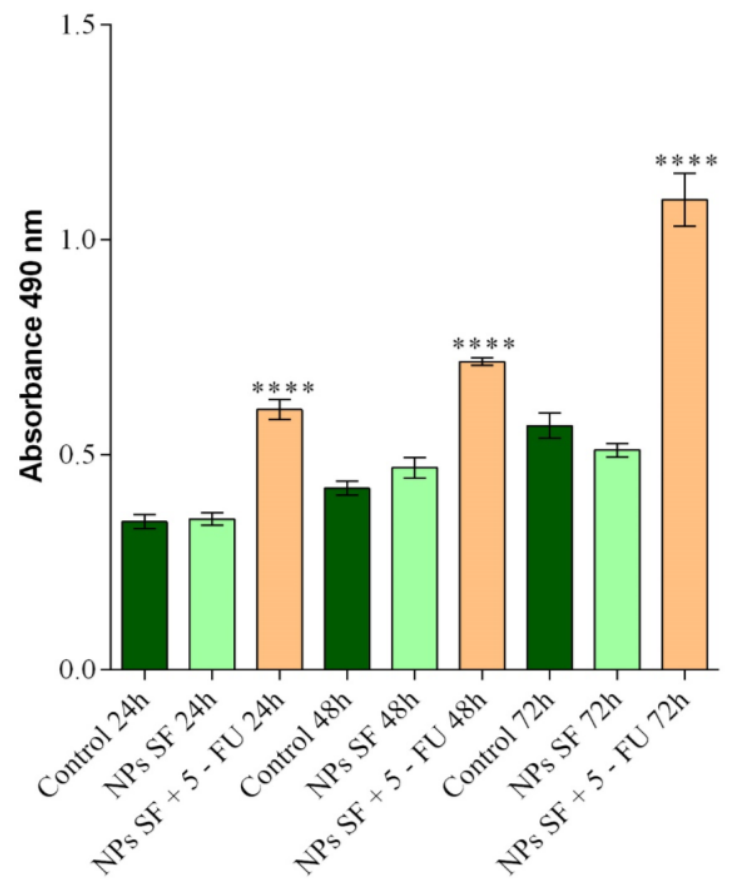

Figure 7.

Graphical representation of the LDH activity in the culture media harvested after $24 \mathrm{~h}, 48 \mathrm{~h}$ and $72 \mathrm{~h}$ of incubation from (i) untreated HT-29 cells; (ii) SF NPs treated HT-29 cells and (iii) 5-FU loaded SF NPs treated HT-29 cells $(* * * * \mathrm{p}<0.0001)$
Our data reveal that the LDH activity was found significantly higher $(* * * * \mathrm{p}<0.0001)$ in the culture media harvested from the HT-29 cells treated with 5-FU loaded SF NPs as compared with the untreated cells or with the cells treated with the unloaded SF NPs. More, the levels of LDH activity in the culture media harvested from the HT-29 cells treated with 5-FU loaded SF NPs was found significantly increased after $72 \mathrm{~h}$ as compared to $48 \mathrm{~h}(* * \mathrm{p}<0.001)$, highlighting the cytotoxic potential of the SF NPs loaded with 5-FU.

HT-29 cells morphology

HT-29 adenocarcinoma cells morphology was investigated by fluorescence microscopy after staining the cytoskeleton fibres with phalloidin-FITC and the cells nuclei with DAPI. The images captured are presented in Figure 8 and show that no alteration, and were produced by the treatment with unloaded SF NPs during $72 \mathrm{~h}$ as compared with the untreated cells. In contrast, the treatment with 5-FU loaded SF NPs induced alterations in terms of actin filaments organization and distribution in the cellular cytoplasm. More, these images are in accordance with those obtained after the Live/Dead staining in terms of cells associations in clusters. 

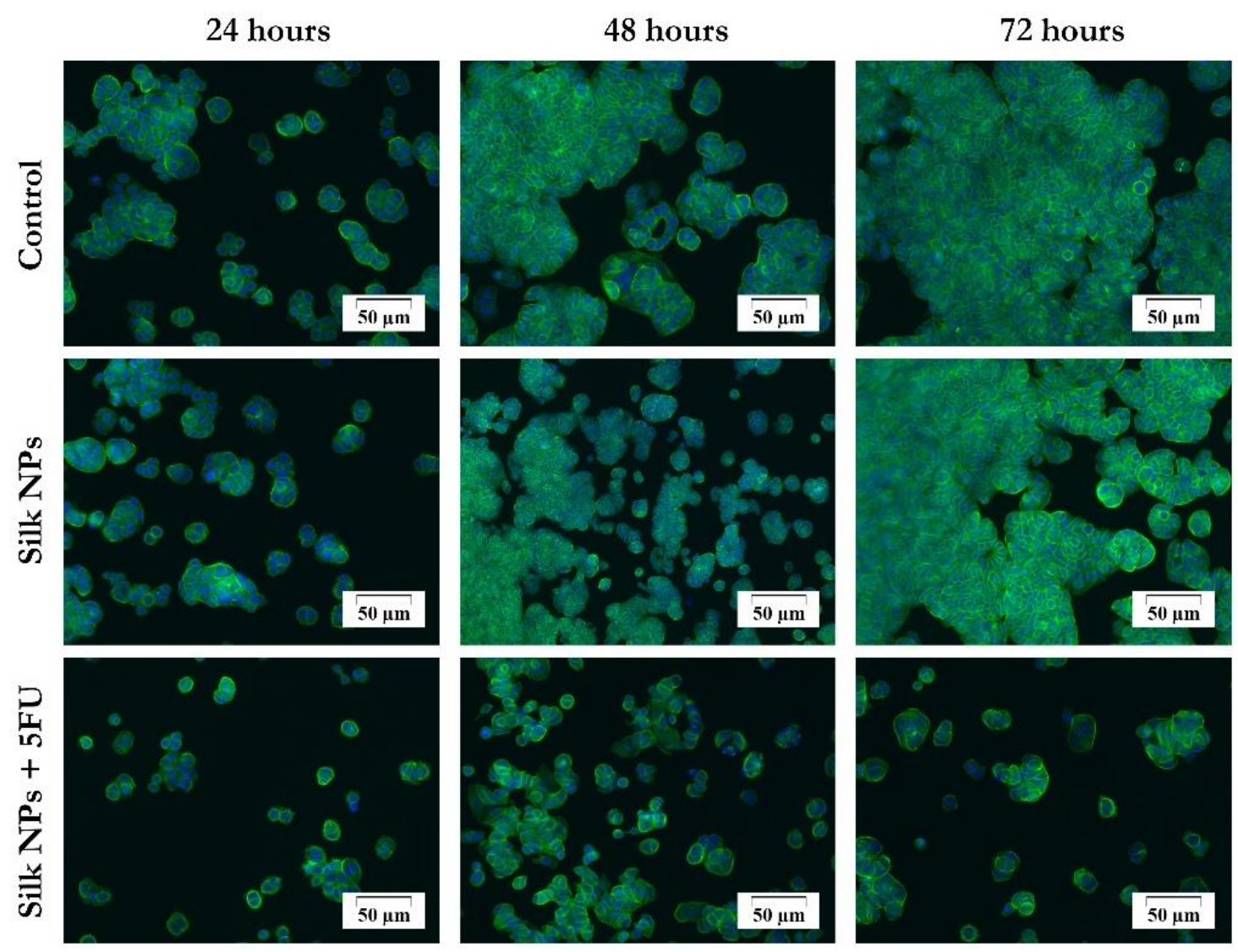

Figure 8.

Fluorescence microscopy images of HT-29 adenocarcinoma cells actin filaments (green fluorescence) and nuclei

(blue fluorescence) after $24 \mathrm{~h}, 48 \mathrm{~h}$ and $72 \mathrm{~h}$ of treatment with unloaded and 5-FU loaded SF NPs $v s$. an untreated monolayer of the same cells

\section{Conclusions}

In conclusion, we have designed and obtained SF NPs by nanoprecipitation method, while optimizing the synthesis protocol accordingly with the polymer's chemistry. By varying the protein solution concentration as the main synthesis parameter, we highlighted the impact of the SF concentration on the 5-FU entrapment and release mechanism. The biological evaluation of the 5-FU loaded SF NPs revealed that the 5-FU loaded original nanocarriers significantly decrease the colorectal adenocarcinoma cells viability and proliferation potential and triggered major morphological alterations of the HT-29 cells structure. In contrast, the simple SF NPs exhibited excellent biocompatibility as the treatment did not affect HT-29 cells viability, proliferation potential or typical morphology. In perspective, the mechanism of action that underlies the cytotoxic effects of the 5-FU loaded SF NPs could be addressed.

\section{Acknowledgement}

This research was financed by the Romanian UEFISCDI, project PN-III-P1-1.1-PD-2016-1966 - PD 131/2018: MagNaNoTer, within PNCDI III.

\section{Conflict of interest}

The authors declare no conflict of interest.

\section{References}

1. Ionescu EM, Tieranu CG, Maftei D, Grivei A, Olteanu AO, Arbanas T, Calu V, Musat S, Mihaescu-Pintia C, Cucu IC, Colorectal cancer trends of 2018 in Romaniaan important geographical variation between northern and southern lands and high mortality versus European averages. J Gastrointest Cancer, 2020; 9: 1-7.

2. Umezawa S, Higurashi T, Komiya Y, Arimoto J, Nobuyuki H, Takeshi K, Motoki I, Nakagema H, Nakajima A, Chemoprevention of colorectal cancer: Past, present, and future. Cancer Sci., 2019; 110(10): 3018-3026.

3. Costea T, Hudiță A, Ciolac OA, Gălățeanu B, Ginghină O, Costache M, Ganea C, Mocanu MM, Chemoprevention of colorectal cancer by dietary compounds. Int J Molec Sci., 2018; 19(12):3787: 1-54.

4. Gherman A, Cainap C, Vesa ȘC, Havasi AD, Trifon A, Cainap SS, Crișan O, Irimie A, Efficacy of cetuximab/panitumumab after previous bevacizumab in metastatic colorectal cancer. Farmacia, 2020; 68(4): 656-664.

5. Lakatos G, Köhne CH, Bodoky G, Current therapy of advanced colorectal cancer according to RAS/RAF 
mutational status. Cancer Metastasis Rev., 2020; 39(4): 1143-1157.

6. Mu Y, Liu Y, Hao Y, Yan L, Liang J, Dong J, Effects of ginsenoside $\mathrm{Rg} 3$ on the proliferation of glioma cells and NF-kB signalling pathway. Farmacia, 2019; 67(5): 899-904.

7. Hudita A, Ioana-Lavric V, Zamfir A, Buburuzan L, Ginghină O, Negrei C, Burcea-Dragomiroiu GTA, Costache M, Ardeleanu C, Radu E, Popa DE, Bârcă M, Iordache N, Ceaușu I, Gălățeanu B, Optimization of a flow cytometry method for the approach of liquid as a therapy modulation tool in patients with colorectal cancer. Farmacia, 2018; 66(5): 853-860.

8. Couvreur P, Nanoparticles in drug delivery: past, present and future. Adv Drug Deliv Rev., 2013; 65(1): 21-23.

9. Hoffman AS, The origins and evolution of "controlled" drug delivery systems. J Control Release, 2008; 132(3): 153-163.

10. Moses MA, Brem H, Langer R, Advancing the field of drug delivery: taking aim at cancer. Cancer Cell, 2003; 4(5): 337-341.

11. Patra JK, Das G, Fraceto LF, Campos EV, del Pilar Rodriguez-Torres M, Acosta-Torres LS, Diaz-Torres LA, Grillo R, Swamy MK, Sharma S, Habtemariam S, Nano based drug delivery systems: recent developments and future prospects. J Nanobiotech., 2018; 16(1): 71: 1-33.

12. Kargozar S, Mozafari M, Nanotechnology and Nanomedicine: Start small, think big. Mater Today, 2018; 5(7): 15492-15500.

13. Banerjee A, Bandopadhyay R, Use of dextran nanoparticle: A paradigm shift in bacterial exopolysaccharide based biomedical applications. Int J Biol Macromol., 2016; 87: 295-301.

14. DeFrates K, Markiewicz T, Gallo P, Rack A, Weyhmiller A, Jarmusik B, Hu X, Protein polymerbased nanoparticles: fabrication and medical applications. Int J Molec Sci., 2018; 19(6): 1717: 1-20.

15. Verma D, Gulati N, Kaul S, Mukherjee S, Nagaich $\mathrm{U}$, Protein based nanostructures for drug delivery. $J$ Pharm., 2018; 2018: 9285854: 1-19.

16. Singh A, Xu J, Mattheolabakis G, Amiji M, EGFRtargeted gelatin nanoparticles for systemic administration of gemcitabine in an orthotopic pancreatic cancer model. Nanomed Nanotechnol., 2016; 12(3): 589-600.

17. Santoro M, Tatara AM, Mikos AG, Gelatin carriers for drug and cell delivery in tissue engineering. $J$ Control Release, 2014; 190: 210-218.

18. Radu IC, Ion AC, Iovu H, Zaharia C, Enzymatic degradation of poly(3-hydroxybutyrate-co-3hydroxyvalerate)nanoparticles loaded with active principles. UPB Sci Bull Ser B, 2020; 82(3): 1-12.

19. Zhang Y, Loh C, Chen J, Mainolfi N, Targeted protein degradation mechanisms. Drug Discov Today Technol., 2019; 31: 53-60.

20. Karlsson J, Vaughan HJ, Green JJ, Biodegradable polymeric nanoparticles for therapeutic cancer treatments. Annu Rev Chem Biomol Rev., 2018; 9: 105-127.

21. Radu IC, Hudita A, Zaharia C, Galateanu B, Iovu H, Tanasa E, Georgiana Nitu S, Ginghina O, Negrei C, Tsatsakis A, Velonia K, Poly (3-hydroxybutyrate-CO3-hydroxyvalerate) PHBHV biocompatible nanocarriers for 5-FU delivery targeting colorectal cancer. Drug Deliv., 2019; 26(1): 318-327.

22. Radu IC, Hudita A, Zaharia C, Stanescu PO, Vasile E, Iovu H, Stan M, Ginghina O, Galateanu B, Costache M, Langguth P, Tsatsakis A, Velonia K, Negrei C, Poly (hydroxybutyrate-co-hydroxyvalerate) (PHBHV) nanocarriers for silymarin release as adjuvant therapy in colo-rectal cancer. Front Pharmacol., 2017; 8: 508: 1-12.

23. Zhang P, Qian X, Zhang Z, Li C, Xie C, Wu W, Jiang $\mathrm{X}$, Supramolecular amphiphilic polymer-based micelles with seven-armed polyoxazoline coating for drug delivery. ACS Appl Mater Inter., 2017; 9(7): 57685777.

24. Hussein YH, Youssry M, Polymeric micelles of biodegradable diblock copolymers: Enhanced encapsulation of hydrophobic drugs. Materials, 2018; 11(5): 688: $1-26$.

25. Zhao Z, Li Y, Xie MB, Silk fibroin-based nanoparticles for drug delivery. Int J Molec Sci., 2015; 16(3): 4880-4903.

26. Radu IC, Biru IE, Damian CM, Ion AC, Iovu H, Tanasa E, Zaharia C, Galateanu B, Grafting versus Crosslinking of Silk Fibroin-g-PNIPAM via TyrosineNIPAM Bridges. Molecules, 2019; 24(22): 4096: 1-18.

27. Pandey V, Haider T, Chandak AR, Chakraborty A, Banerjee S, Soni V, Surface modified silk fibroin nanoparticles for improved delivery of doxorubicin: Development, characterization, in-vitro studies. Int J Bio Macromol., 2020; 64: 2018-2027.

28. Kou L, Sun J, Zhai Y, He Z, The endocytosis and intracellular fate of nanomedicines: Implication for rational design. Asian J Pharm Sci., 2013; 8(1): 1-10.

29. Etheridge ML, Campbell SA, Erdman AG, Haynes CL, Wolf SM, McCullough J, The big picture on nanomedicine: the state of investigational and approved nanomedicine products. Nanomed Nanotechnol., 2013; 9(1): $1-4$.

30. Dobrovolskaia MA, Aggarwal P, Hall JB, McNeil SE, Preclinical studies to understand nanoparticle interaction with the immune system and its potential effects on nanoparticle biodistribution. Molec Pharm., 2008; 5(4): 487-495.

31. Karmali PP, Simberg D, Interactions of nanoparticles with plasma proteins: implication on clearance and toxicity of drug delivery systems. Expert Opin Drug Del., 2011; 8(3): 343-357.

32. Wen H, Jung H, Li X, Drug delivery approaches in addressing clinical pharmacology-related issues: opportunities and challenges. AAPS J., 2015; 17(6): 1327-1340.

33. Patra JK, Das G, Fraceto LF, Campos EV, del Pilar Rodriguez-Torres M, Acosta-Torres LS, Diaz-Torres LA, Grillo R, Swamy MK, Sharma S, Habtemariam S, Nano based drug delivery systems: recent developments and future prospects. J Nanobiotechnol., 2018; 16(1): 71: $1-33$

34. Chandran SP, Natarajan SB, Chandraseharan S, Shahimi MS, Nano drug delivery strategy of 5fluorouracil for the treatment of colorectal cancer. $J$ Cancer Res Pract., 2017; 4(2): 45-48.

35. Bunea MC, Vasile E, Galateanu B, Hudita A, Serban M, Zaharia C, Silk fibroin films decorated with magnetic 
nanoparticles for wound healling applications. Materiale Plastice, 2017; 54(1): 83-87.

36. Zhang YQ, Shen WD, Xiang RL, Zhuge LJ, Gao WJ, Wang WB, J Nanopart Res., 2007; 9: 885-900.

37. Rao JP, Geckeler KE, Polymer nanoparticles: preparation techniques and size-control parameters. Prog Polym Sci., 2011; 36(7): 887-913.

38. Lince F, Marchisio DL, Barresi AA, Strategies to control the particle size distribution of poly- $\varepsilon$ caprolactone nanoparticles for pharmaceutical applications. J Colloid Interface Sci., 2008; 322(2): 505-515.
39. Mottaghitalab F, Farokhi M, Shokrgozar MA, Atyabi F, Hosseinkhani H, Silk fibroin nanoparticle as a novel drug delivery system. J Control Release, 2015; 206: 161-176.

40. Cheng G, Cai Z, Wang L, Biocompatibility and biodegradation of poly (hydroxybutyrate)/poly (ethylene glycol) blend films. J Mater Sci Mater Med., 2003; 14(12): 1073-1078. 